\title{
Publication Requirements and Tenure Approval Rates: An Issue for Academic Librarians
}

\author{
W. Bede Mitchell and \\ L. Stanislava Swieszkowski
}

One hundred and thirty-eight members of the Center for Research Libraries responded to a survey designed to test the hypothesis that where tenure-track librarians are required to do research and publish, an inadequate research and publication record would be the most frequent cause for the rejection of the librarians' tenure applications. The hypothesis proved valid, but only for a small percentage of the librarians. The study revealed a generally high tenure approval rate (81.5 percent) for academic librarians compared to the national average for other academic faculty (58 percent).

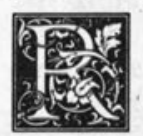

ecent studies and estimates indicate that some form of faculty status has been achieved by as many as 75 percent of practicing academic librarians. ${ }^{1}$ Librarians' experience has shown that the benefits of faculty status are usually accompanied by new responsibilities. An issue of particular concern arises when institutions adopt promotion and tenure criteria for librarians that are similar, if not identical, to those used for the instructional faculty. When these criteria include the requirement to do research and publish, many librarians find themselves in unfamiliar territory because of

... the very nature of library work as it is currently structured. The daily work load of most academic librarians usually limits, sometimes severely, the possibility of systematically developing and pursuing individual research interests. So too does the fact that most academic librarians have 12 -month rather than 9-month contracts. Finally, even where research is required for professional advancement, there typically has been a lack of administrative support for it, exemplified by the failure to provide released time, clerical assistance, and funding in adequate amounts. ${ }^{2}$

This scenario suggests that librarians with faculty status may find it difficult to earn promotion and tenure when their research and publication standards are similar to those that their colleagues on the instructional faculty must meet. Traditionally, unlike the teaching faculty, research and publication has not been part of the job for the majority of academic librarians. While some librarians found the time to publish, as demonstrated by the numerous and long-published library journals, most did not. In fact, publishing was never an issue until librarians began to acquire "tenure-track" status. Therefore, the authors postulated that when academic librarians are required to produce research and publish in order to achieve tenure, the lack of such production would be the most frequent cause for an applicant to be denied tenure.

\section{SELECTED RELEVANT LITERATURE}

In her 1977 article "Publication Activity

W. Bede Mitchell is circulation librarian at Montana State University, Bozeman, 59717. L. Stanislava Swieszkowski was creative arts librarian at Montana State and is now art librarian, New York Public Library, New York 10012. 
Among Academic Librarians," Paula de Simone Watson suggests that "librarians with faculty status are likely to suffer where promotion and tenure decisions concerning them are subjected to the same review procedures used to evaluate the teaching faculty" because of "the low productivity found by the present study for professionals with five or fewer years of experience. ${ }^{\prime 3}$ Watson surveyed the publication records of librarians at ten large university libraries for the period 1970-74. She found that the median number of publications per year for publishing librarians was two. If book reviews were not included, the rate dropped to one publication per year. For all academic librarians at the surveyed institutions, the publication rate was significantly less than one publication per year. Of particular concern was the low output of librarians with five years or less experience (those within the tenure evaluation period). These librarians made up one-third of the surveyed staffs but produced only 18 percent of the publications for that period.

In 1980, Rayman and Goudy reported the results of a survey of sixty-eight libraries holding membership in the Association of Research Libraries (ARL). They found that only about 15 percent of librarians in the responding libraries were required to publish and that all librarians in this group had faculty status and were eligible for tenure. ${ }^{4}$

Thomas G. English surveyed the status of librarians at the eighty-nine U.S. academic member-institutions of ARL for the year 1982 and discovered that few institutions seemed to evaluate librarians under criteria used for instructional faculty. The most frequent evaluation model used at institutions with faculty status for librarians required that the librarians "meet two distinct sets of criteria: one set designed to measure performance as librarians; the other set designed to measure performance as faculty."

\section{METHODOLOGY}

To determine whether or not research and publication criteria are major obstacles to academic librarians seeking tenure, a fourteen-question survey was sent to the directors of the one hundred and fortyseven U.S. academic libraries that are full or associate members of the Center for $\mathrm{Re}$ search Libraries (see appendix A). The first three questions requested information regarding the status of librarians as defined at each institution, the length of time that the status had been in effect, and the eligibility or ineligibility for tenure. The rest of the questionnaire was to be completed only by those institutions where librarians were eligible for tenure and were required to perform research and publish in order to achieve tenure. The questions dealt with the kinds of publication standards to be met, the types of support available for librarians to carry out research, and the number of librarians who had and had not been granted tenure during the five years before receipt of the survey (mailed in April 1983). After follow-up mailings, 138 responses were received ( 94.5 percent response rate). One library director did not wish to participate in the survey, and eight other institutions did not respond.

\section{FINDINGS}

The data were grouped into four categories for analysis: by aggregate data; by college and university; by public and private institution; and by tenure eligibility/publishing requirement.

Of the 138 respondents, 50 (36.2 percent) claimed to have faculty status equivalent to the teaching faculty (see table 1 ). More than half, 72 (52.2 percent), had an academic status separate or different from the teaching faculty. Only 16 (11.6 percent) claimed a nonacademic professional status. These results parallel the findings of English, Rayman and Goudy. However, it is important to note that the authors here, unlike English, did not categorize each institution according to a predetermined definition of faculty status. Respondents to this study were asked whether or not they had "faculty status equivalent to the academic instructional faculty." This definition allows for the varying interpretations of the term "faculty status" that may exist on different campuses. The authors were only concerned with whether or not librarians on a 
TABLE 1

LIBRARIAN STATUS-138 RESPONDENTS

\begin{tabular}{|c|c|c|c|c|c|c|c|c|}
\hline \multirow{2}{*}{$\frac{\text { Categories }}{\text { Public }}$} & \multicolumn{2}{|c|}{$\begin{array}{l}\text { Equivalent } \\
\text { Faculty Status } \\
\text { (50 Institutions) }\end{array}$} & \multicolumn{2}{|c|}{$\begin{array}{c}\text { Different } \\
\text { Academic Status } \\
\text { (72 Institutions) }\end{array}$} & \multicolumn{2}{|c|}{$\begin{array}{l}\text { NonAcademic } \\
\text { Professional } \\
\text { Status } \\
\text { (16 Institutions) }\end{array}$} & \multirow{2}{*}{$\begin{array}{c}\text { Other } \\
0\end{array}$} & \multirow{3}{*}{$\begin{array}{l}\text { Total } \\
138\end{array}$} \\
\hline & 44 & \multirow{2}{*}{50} & 51 & \multirow{2}{*}{72} & 5 & \multirow{2}{*}{16} & & \\
\hline Private & 6 & & 21 & & 11 & & 0 & \\
\hline College & 4 & \multirow{2}{*}{50} & 2 & \multirow{2}{*}{72} & 2 & \multirow{2}{*}{16} & 0 & \multirow{2}{*}{138} \\
\hline University & 46 & & 70 & & 14 & & 0 & \\
\hline $\begin{array}{l}\text { Tenure \& } \\
\text { Publication }\end{array}$ & 27 & \multirow{3}{*}{50} & 11 & \multirow{3}{*}{72} & 0 & & 0 & \multirow{3}{*}{138} \\
\hline $\begin{array}{r}\text { Tenure \& No } \\
\text { Publication }\end{array}$ & 18 & & 22 & & 3 & 16 & & \\
\hline No Tenure & 5 & & 39 & & 13 & & 0 & \\
\hline
\end{tabular}

given campus were categorized in a similar manner to other faculty on that campus. Therefore, the faculty-status answers reported in the survey do not necessarily reflect conformance or nonconformance to the ACRL definition of faculty status. It is significant that of the 70 institutions that responded to both English's survey and this survey, 62 indicated, in this survey, that they held the status for which they were categorized by English. Seven of the remaining 8, while categorized by English as having faculty status, indicated in this survey that their status was not equivalent to the instructional faculty.

Sixty-four (46.6 percent) of the institutions have held their particular status for more than sixteen years. Thirty-three (23.9 percent) of the respondents acquired their present status in the last eleven to fifteen years, 24 (17.4 percent) in the last six to ten years, and 13 (9.4 percent) in the last five years. Four institutions ( 2.9 percent) did not know how long they have held their particular status. It is interesting to note that 27 percent of all respondents have changed their status in the last ten years. Sixteen institutions have changed their librarians' status to nontenure track, 12 institutions have changed their status to tenure with no publication required, and 9 institutions have changed their tenure-track status to include publication. Similarly, English's survey revealed that institutions "were no longer inclined to shift librarians from non-faculty to faculty status, as was commonly done in the sixties and early seventies. Rather, the few, recent changes reported were all in the opposite direction, from faculty status to a non-faculty or modified faculty status. ${ }^{\prime \prime 6}$

By a slight majority, 81 (58.7 percent) institutions have tenure-track status for most or all of their librarians, while 57 (41.3 percent) do not. (For a comparison of this study with the English and Rayman and Goudy studies, consult table 2.) Of those 81 institutions, 38 (46.9 percent) require evidence of research and publication before a librarian can achieve tenure, and

TABLE 2

ELIGIBILITY OF LIBRARIANS FOR TENURE

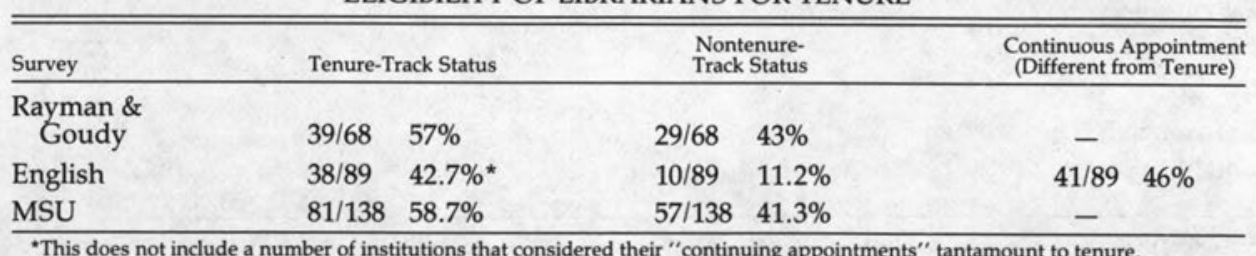

"This does not include a number of institutions that considered their "continuing appointments" tantamount to tenure. 
42 (53.1 percent) do not require publication, although some indicated that publishing is encouraged (see table 3). Based on the survey results, the vast majority (100 out of 138 , or 72.5 percent) of the academic librarians at the surveyed institutions were not required to show evidence of research and publication. Consequently, it is wise to bear in mind that the responses to the remaining questions on publishing requirements for tenure reflect practices at only a small group of institutions.

Within the last five years, 329 librarians at the 38 responding institutions were re-

TABLE 3

RESEARCH AND PUBLICATION REQUIREMENTS FOR TENURE

\begin{tabular}{lcccc}
\hline \hline Survey & \multicolumn{2}{c}{ Yes } & \multicolumn{2}{c}{ No } \\
\hline Rayman \& & & & & \\
$\quad$ Goudy & $10 / 68$ & $14.7 \%$ & $58 / 68$ & $85.3 \%$ \\
English & - & & - & \\
MSU & $38 / 81$ & $46.9 \%$ & $43 / 81$ & $53.1 \%$ \\
\hline
\end{tabular}

viewed for tenure (see table 4). Sixty-one (18.5 percent) of these were not granted tenure; 268 ( 81.5 percent) achieved tenure. Thirty-five ( 57.4 percent) of those 61 librarians were denied tenure because of an inadequate research/publication record. Twenty-one ( 34.4 percent) were denied tenure for inadequate job performance and 10 (16.4 percent) for unknown reasons. Four (6.6 percent) were denied because of an inadequate service record (committee and professional service); and 1 person (1.6 percent) had an inadequate continuing education record. (In some cases more than one reason was given.)

Of the 38 institutions that require research and publication, 97.4 percent gave credit for publishing books, chapters in books, and refereed journal articles in the field of library/information science.? Among the institutions, 89.5 percent gave credit for these publications outside the library field. Conference papers within the field of library science were given credit at 97.4 percent of the institutions; 81.6 per-

TABLE 4

TENURE APPROVAL RATES (FIVE-YEAR PERIOD)*

\begin{tabular}{lccc}
\hline \hline Institution & $\begin{array}{c}\text { \% of Denied } \\
\text { Tenure } \\
\text { Applications }\end{array}$ & $\begin{array}{c}\text { of Librarians } \\
\text { Applying } \\
\text { for Tenure }\end{array}$ & $\begin{array}{c}\text { \% of Tenure } \\
\text { Approval } \\
\text { Rate }\end{array}$ \\
\hline 1 & 3 & 13 & 76.9 \\
2 & 1 & 6 & 83.3 \\
3 & 1 & 3 & 66.7 \\
4 & 3 & 20 & 85 \\
5 & 1 & 10 & 71.4 \\
6 & 2 & 7 & 75 \\
7 & 5 & 20 & 80 \\
8 & 1 & 5 & 93.3 \\
9 & 1 & 15 & 64.3 \\
10 & 5 & 14 & 66.7 \\
11 & 2 & 6 & 68 \\
12 & 8 & 25 & 90 \\
13 & 2 & 20 & 83.6 \\
14 & 2 & 13 & 71.4 \\
15 & 2 & 6 & 92.9 \\
16 & 1 & 7 & 20 \\
17 & 2 & 14 & 80 \\
18 & 1 & 5 & 77.8 \\
19 & 4 & 10 & 20 \\
20 & 2 & 9 & 79.5 \\
21 & 2 & 5 & 100 \\
22 & 4 & 39 & $81.5 \%$ \\
23 through 38 & 8 & 57 & \\
Total & 0 & 329 & Average \\
& 61 & & 89 \\
\hline
\end{tabular}

*For the thirty-eight responding institutions where librarians have tenure-track status and are required to publish. 
cent of the institutions gave credit for conference papers outside the library field. Unrefereed journal articles in the field were given credit by 89.5 percent of the institutions; however, only 68:4 percent gave credit for those publications in other fields. Book reviews in the field of library science were given credit by 84.2 percent of the institutions; book reviews outside the field of library science received credit at 73.7 percent of the institutions. Inhouse publications dealing with the library science field received credit at 63.2 percent of the institutions, while only 42.1 percent of the institutions gave credit for publications in other fields. For other types of publications in the field of library science, 18.4 percent of the institutions gave librarians credit; within other fields, 13.2 percent of the institutions gave them credit. The authors did not query the weight given to one type of publication over another. Readers are referred to the report of a survey published in College $\mathcal{E}$ Research Libraries by Geahigan, Nelson, Saunders, and Woods. ${ }^{8}$

None of the 38 institutions required that the librarians produce a specific number of publications. As a result, there were no responses to the inquiry regarding how the standards relative to the specific number of publications were applied to librarians, i.e., are they agreed upon individually or are they the same for all librarians?

At 29 (76.3 percent) of the institutions, librarians are eligible for sabbaticals, and at 19 (50 percent), librarians are eligible for release time (see table 5). At 21 ( 52.6 percent) of the institutions, it was felt that the research and publication standards for librarians were different from those applied to the teaching faculty. Seventeen (44.7 percent) of the institutions felt that there were no differences.

\section{TABLE 5}

AVAILABILITY OF RELEASE TIME/RESEARCH LEAVE

\begin{tabular}{lllll}
\hline \hline Survey & \multicolumn{2}{c}{ Yes } & \multicolumn{2}{c}{ No } \\
\hline Rayman \& & & & & \\
Goudy & $35 / 68$ & $51 \%$ & $33 / 68$ & $49 \%$ \\
English & $72 / 89$ & $80.8 \%$ & $17 / 89$ & $19.2 \%$ \\
MSU & $19 / 38$ & $50 \%$ & $19 / 38$ & $50 \%$ \\
\hline
\end{tabular}

The library provided funding for librarians at 18 (47.4 percent) institutions, while at 20 (52.6 percent) of the libraries, it did not (see table 6). The colleges and universities made funding available to librarians at 34 (89.5 percent) of the institutions, 2 (5.3 percent) of the libraries were not eligible, and 2 had no institutional funding.

\section{TABLE 6}

AVAILABILITY OF RESEARCH FUNDING

\begin{tabular}{lllll}
\hline \hline Survey & \multicolumn{2}{c}{ From Library } & \multicolumn{2}{c}{ From University } \\
\hline Rayman \& & & & & \\
$\quad$ Goudy & $18 / 68$ & $23 \%$ & $40 / 68$ & $51 \%$ \\
English & $64 / 89$ & $71.9 \%$ & - & \\
MSU & $18 / 38$ & $47.4 \%$ & $34 / 38$ & $89.5 \%$ \\
\hline
\end{tabular}

\section{CONCLUSIONS}

1. The responses provided by the institutions in the sample support the hypothesis that the most frequent cause for librarians being denied tenure is an inadequate research and publication record. It should be noted that at some institutions, explicit reasons are rarely or never given by review boards when tenure applications are denied. Therefore, some of the respondents may only have been speculating about the reason(s) why their librarians were rejected (although none indicated that they were doing so).

2. The high tenure rate ( 81.5 percent) reported by the respondents who require research and publication for tenure (see table 5) compares very favorably with the tenure approval rates of other faculty. A study by Frank J. Atelsek and Irene L. Gomberg found that in 1978-79, 12,400 individuals were formally reviewed for tenure nationwide, and 58 percent were approved. ${ }^{9}$

3. The high tenure approval rates for librarians required to publish are consistent from respondent to respondent, as only 2 out of 38 institutions (see table 2 ) reported approval rates of less than 64.3 percent (see table 5). High tenure rates occurred regardless of factors such as availability of release time, sabbaticals, etc.

4. Based on the results of this study, it would appear that Watson's theory that li- 
brarians who are required to publish may have problems achieving tenure is unfounded. It may be significant, however, that of the 37 respondents who changed their librarians' status during the last ten years, only 9 have adopted publication requirements for achieving tenure. By contrast, 12 institutions adopted tenure-track status that does not require publication, and 16 institutions changed to nontenuretrack status. The survey did not solicit in- formation regarding the nature of, and reasons for, these changes. ${ }^{10}$

5 . Eighty-one (58 percent) of all the respondents reported tenure track status for most or aH of their librarian positions, yet only 38 of these institutions require evidence of research and publication before granting tenure to librarians. Consequently, it would appear that tenure-track status for librarians does not always imply the requirement to publish.

\section{REFERENCES AND NOTES}

1. C. J. Schmidt, "Faculty Status in Academic Libraries: Retrospective and Prospect," in New Horizons for Academic Libraries, ed. R. D. Stueart and R. D. Johnson (New York: K. G. Saur, 1979), p.411.

2. Darrell L. Jenkins, M. Kathleen Cook, and Mary Anne Fox, "Research Development of Academic Librarians: One University's Approach," Journal of Academic Librarianship 7:83-86 (May 1981).

3. Paula de Simone Watson, "Publication Activity Among Academic Librarians," College \& Research Libraries 38:382 (September 1977).

4. Ronald Rayman and Frank W. Goudy, "Research \& Publication Requirements in University Libraries," College \& Research Libraries 41:43-48 (January 1980).

5. Thomas G. English, "Librarians Status in the Eighty-Nine U.S. Academic Institutions of the Association of Research Libraries: 1982," College \& Research Libraries 44:199-208 (May 1983).

6. English, "Librarian Status in U.S. Academic Institutions," p.207.

7. Priscilla Geahigan, Harriet Nelson, Stewart Saunders and others, "Acceptability of NonLibrary/Information Science Publications in the Promotion \& Tenure of Academic Librarians," College \& Research Libraries, 42: 571-75 (Nov. 1981).

8. One college with religious affiliation gave no credit to publishing done within the library science field.

9. Tenure Practices at Four-Year Colleges \& Universities, by Frank J. Atelsek and Irene L. Gomberg, Higher Education Panel Report no. 48 (Washington, D.C.: American Council on Education, 1980), p.1-49.

10. It is possible that some or all of these changes were due to difficulties encountered by librarians attempting to meet publication requirements.

\section{APPENDIX A: QUESTIONNAIRE}

Name of Institution

1. Which of the following best describes the status of librarians at your institution? (Please check the appropriate responses.)

a. faculty status equivalent to the academic instructional faculty

b. academic status separate or different from the academic instructional faculty

c. nonacademic professional status

d. Other (please explain)

2. How long have the librarians at your institution had this status?

0-5 years 6-10 years 11-15 years $16+$ years

3. Are your librarians eligible for tenure? yes no 
4. If librarians are eligible for tenure, must they show evidence of research and publication in order to achieve tenure? yes no If the answer to \#4 is no, it is not necessary to go further. Please return the questionnaire as completed thus far. Thank you.

5. If research and publication is required of librarians in order that they may earn tenure, for which of the following kinds of research do librarians receive credit? (Please check the appropriate response.)

Library/information

science topics

\& publications
Topics \& pubs. in other fields

books or chapters in books

refereed journal articles

unrefereed journal articles

conference papers

book reviews

in-house publications

other (please specify)

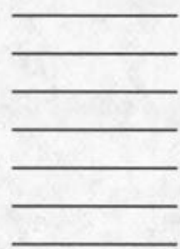

6. Is there a specified number of publications that librarians are required to produce in order to achieve tenure?

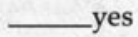

no

7. If a specified number of publications is required, please check the appropriate response if the standards are either (a) agreed upon periodically between each librarian and his/her supervisor, or (b) the same for all librarians.

8. Please check the appropriate response if librarians are eligible for (a) release time, or (b) sabbaticals.

9. Are the research and publication standards for librarians different from those applied to other faculty on campus in recognition of the librarians' different work responsibilities?

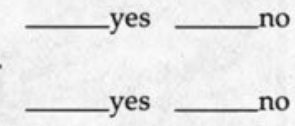

10. Is funding available from the library for librarians to carry out research for publication?

11. If the institution makes funding available to academic faculty for research, are librarians also eligible to receive this funding?

12. At your institution, how many librarians have been reviewed for tenure in the last five years (or since librarians became eligible for tenure, if that was less than five years ago?)

13. How many of those applicants were not granted tenure?

14. Please indicate how frequently each of the following factors resulted in the rejection of an application for tenure. (For example, reason (a) may have been cited or inferred in four cases of rejection, so " 4 " should be entered next to (a).

a. inadequate research/publication record

b. inadequate job performance

c. inadequate service record (committee service, professional service)

d. inadequate continuing education record

e. unknown

f. other (please specify or comment)

Thank you very much for completing this questionnaire. Your time and effort is greatly appreciated.W. Bede Mitchell \& L. Stanislava Swieszkowski. 


\section{It's Your Choice.}

đUniversin,

03054. An equal oppoi tunity/aftirilia tive action employer.

ACQUISITIONS HELP

ACQUISITIONS ASSISTANTS needed

to handle purchase of foreign micro

form collections. Responsible for all

ise form collections. with foreign micro:

iss correspond handling currency ex-

publishers, handling currency ex-

lems, and inspecting rolls and fiche

for claims. Requirements include flu-

loncy in at least three foreign lan-

ency in at least three for tolerance.

guages and high frustration

Starting sa

REFERENCE LIBRARIAN: Respon:

sible for general reference.

tic insto ?
REt

sible

searche.

the M.F

instituti

resume

Suzac

Health

ern Un
03054 . A.

tive acty

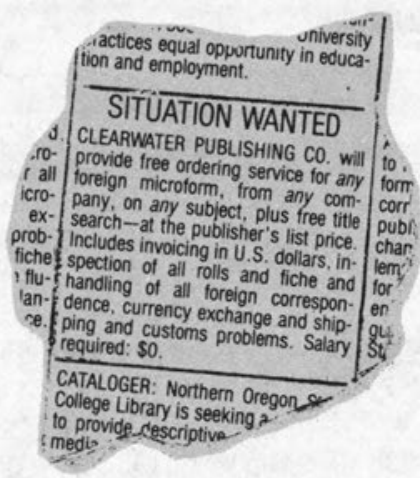

provide descriptive

Don't you wish all your choices were this easy? 